\title{
Tourists' Perceptions of Heritage Tourism Development in Danish-Osu, Ghana
}

Aaron K. B. Yankholmes ${ }^{1, *}$ and Oheneba A. Akyeampong ${ }^{2}$

${ }^{1}$ Universidad de Deusto, Instituto de Estudios de Ocio, Bilbao, Bizkaia, Spain

${ }^{2}$ Department of Hospitality and Tourism Management, University of Cape Coast, P.M.B Cape Coast, Ghana

\section{ABSTRACT}

This paper examines the tourist perceptions at Danish, Osu-Ghana within the dark tourism or slavery heritage contexts. Using Cohen's (1979) typology of tourist experience, we differentiate between tourist knowledge of a heritage site relative to socio-demographic indices. The results indicate that tourists' perception of DanishOsu reflect their knowledge of the site in relation to its cultural heritage attributes. In addition, it was found that tourists have dual experiences of the site: those that relate to recreational pursuits of heritage sites and those that ascribe meanings based on their background. The contemporary nature and use of Transatlantic Slave Trade relics for tourism development makes the case of the Danish-Osu more delicate considering the ethical implications of interpreting the community's past to tourists as the borderlines are unclear. Copyright (c) 2010 John Wiley \& Sons, Ltd.

Received 23 September 2009; Revised 25 January 2010; Accepted 1 March 2010

Keywords: Transatlantic Slave Trade; heritage tourism; dark tourism; slavery heritage; tourists; Danish-Osu.

*Correspondence to: A. K. B. Yankholmes, Universidad de Deusto, Instituto de Estudios de Ocio, Avda. de las Universidades 24, Bilbao, Bizkaia, Spain.

E-mail: ayankholmes@yahoo.co.uk

\section{INTRODUCTION}

$\mathrm{H}$ eritage tourism is one of the most rapidly growing segments of the tourism industry and has generated a substantial body of literature (Garrod and Fyall, 1998; Herbert, 2001; Poria et al., 2001; McKercher and du Cros, 2002; Chhabra et al., 2003). Many travellers to historic and cultural sites consider their experiences at these attractions as value-added, thereby increasing the chances of repeat visits. Most of such visitors are disenchanted with the traditional sea, sun, sand (SSS) tourism products offered by mass destinations around the world and they now seek the more authentic experiences offered by heritage attractions (Timothy, 1997; McKercher, 2002).

Many scholars now accept that, conceptually, heritage tourism includes tourism-related activities that have been inherited (Lowenthal, 1985; Yale, 1991). Timothy and Boyd (2006, p. 4) stress that 'heritage is not simply the past, but the modern-day use of elements of the past'. On their part, Poria et al. (2006a, p. 1048) emphasise the issue of motivation, and define heritage tourism as 'a sub-group of tourism, in which the main motivation for visiting a site is based on the place's heritage characteristics according to the tourists' perception of their own heritage'. Chhabra et al. (2003) take up the definition of heritage tourism from the demand and supply sides of the coin. They re-echo the sentiments of the foregoing authorities in an equally emphatic way, stressing that

in terms of demand, heritage tourism is a representative of many contemporary visitors' desire (hereafter, tourists) to

Copyright (C) 2010 John Wiley \& Sons, Ltd. 
directly experience and consume diverse past and present cultural landscapes, performances, foods, handicrafts, and participatory activities. On the supply side, heritage tourism is widely looked to as a tool for community economic development and is often actively promoted by local governments and private businesses. (Chhabra et al., 2003, p. 703)

Gauged by the above definitions, Transatlantic Slave Trade (TAST) relics and resources fit into the concept of heritage tourism. Some scholars have also begun to explore the phenomenon of 'dark tourism' (Foley and Lennon, 1996), which provides a starting point for the study of tourism related to sites of death and tragedy. From the 1990s onwards the introduction of concepts such as 'thanatourism', 'black spot' tourism and 'atrocity heritage' led to more attention being paid to the packaging and consumption of sites associated with death or disaster (Rojek, 1993; Seaton, 1996; Tunbridge and Ashworth, 1996). Battle sites and death camps are among the most researched places in this regard (Young 1993; Seaton 1999). Others are historical sites associated with former communist, fascist or apartheid regimes (Wight and Lennon, 2007), slavery heritage (Teye and Timothy, 2004), sites of confinement and punishment (Blackburn, 2000; Strange and Kemp, 2003) and those associated with the assassination or death of famous personalities such as President John F. Kennedy and Diana, Princess of Wales (Walter, 2001). In recent times, Bremer (2004) has focused on drawing the borderline between religion and tourism at the site of the fallen World Trade Center Towers in New York.

On the other hand, some writers have questioned the utility of using TAST or slavery resources for purposes of tourism promotion (Austin, 2000, 2002; Teye and Timothy, 2004). For example, Boakye and Dei (2007) argue that the issue is more delicate given that most former slave sites must still overcome the apprehension of a tourism product that reminds residents of their unfortunate ancestors and continuously challenges their dignity. These sentiments are also reiterated by Yankholmes et al. (2009) who maintain that any attempts to make sense of or understand com- munity support for tourism development in former slave sites are properly done within the overall framework of a long-term heritage tourism planning that ensures sustainability. To them, the use of TAST resources for tourism promotion must take cognisance of the allpervasive influence of community attachment by residents.

The scenario just outlined is especially contentious from a tourism perspective when 'different groups of visitors assessing the same visitor site see themselves as being at conflict as a result of historical events of the past associated with the site' (Austin, 2002, p. 448). According to Meyersohn (1981), an attraction assumes cultural significance because it provokes a heightened awareness of a historical past and provides a connection with human beings. Thus, in tune with the TAST debate and the controversy over the use of heritage resources, tourist visits to contested heritage sites are now at a crossroads between heritage producers and consumers for several reasons. First, there has been significant growth in tourism associated with sites of death, disaster and depravity (Lennon and Foley, 1999). Bruner (1996, p. 291) has observed that many African-Americans come to Ghana to seek their ancestry, 'to experience one of the very sites from which their ancestors may have begun the torturous journey to the New World'. Second, there is still a need to understand better the supply side of heritage tourism, including how resources are 'marked' as heritage sites in different cultures and the unique management challenges and solutions in different heritage settings (Timothy and Boyd, 2006). While for some, interpreting the inhuman tragedy of TAST is a means of preserving and conserving not just history but also heritage, others see it as reinforcing personal and collective identity. For Swarbrooke (1993), the reality of a product or experience is probably less important than the consumer's perception of it. Poria et al. (2001) go as far as to suggest that understanding tourists' perception of heritage sites would help in the management of such (heritage) sites with respect to pricing policy, the mission of heritage attractions and understanding visitor profiles, as well as public funding and sustainable management. Therefore, exploring the values attributed to dark

Int. J. Tourism Res. 12, 603-616 (2010) 
tourism sites by tourists and the management of those sites are critical to destinations that possess such resources.

Closely associated with the above is the relationship between the tourist and the space visited in terms of identifying the value sought and gained from visiting heritage attractions (Poria et al., 2006a, 2006b). According to Timothy and Boyd (2006), two views serve to highlight the differences in the approaches and conception of heritage tourism in the academic community. The more common one emphasises the heritage presented at the site, i.e. the object as the core of the phenomenon (Peleggi, 1996; Garrod and Fyall, 2001). The second approach provides the links between the subject-the tourist-and the object-the historic artefact(s) - presented (Poria et al., 2001). This reflects the dichotomy between the 'uses' and 'users' of heritage as well as 'producers' and 'consumers' (Tunbridge and Ashworth, 1996).

Building on the propositions by Poria et al. (2001), the present study adopts the second approach. From the perspective of dark or slavery heritage tourism, issues regarding tourists' perceptions of tourism promotion in contested sites have been limited even if growing as researchers seek to measure visitor emotions (Brunner, 1996; Best, 2007), motivation (Seaton, 1996) and anxiety (Foley and Lennon, 2000). The purpose of the study was threefold. First, it sought to ascertain tourists' knowledge and understanding of the site they were visiting and the meanings they ascribed to the heritage space. Second, there is an examination of their attitudes towards heritage tourism development. Finally, it explored the ethical implications for the future direction of heritage tourism in the area.

To facilitate our understanding of the dynamics of tourist experiences, including heritage tourism, Cohen (1979) put forward a typology of tourist experiences based on place and significance of the given tourist experience of the world. Basically, this world view of tourists is typified by their attitude to a perceived 'centre' and the location of that centre in relation to the society in which the tourist lives. Cohen (1979) surmises that first, there is the recreational experience that is a form of entertainment, based on the belief in the recupera- tive or restorative power of a tourist trip; it is a secular rational belief in the value of leisure activities. Second and closely linked to the recreational type of tourist experiences is the diversionary - a mere escape from the boredom and meaninglessness of routine everyday existence-into the 'forgetfulness of vacation'. The experiential stresses the quest for meaning outside the confines of one's own society, the search for authentic experiences. The fourth is the experimental - a quest for an alternative in many different directions. Finally, existential tourists are fully committed to an elective spiritual centre, external to their mainstream native society and which is epitomised in some sites of death and tragedy. Cohen opines that existential experiences of tourists are similar to those experienced at pilgrimage sites because 'real' life is at the centre. Thus, Cohen's (1979) tourist typology of experiences is used in this paper in understanding experiences of tourists to contested heritage sites.

\section{CHARACTERISTICS OF HERITAGE TOURISTS}

One approach to understanding tourists' perceptions of heritage destinations is identifying the characteristics of the tourists. However, the word 'tourist' needs further elaboration here. It is used in the sense in which Cohen (1974, p. 533) intended it: as 'a voluntary, temporary traveller, travelling in the expectation of pleasure from the novelty and change experienced on a relatively long and non-recurrent trip'. While a multitude of variations of this definition exist, Cohen's original version captures the fundamental elements of the concept: purpose of visit and the profundity of experiences. In an earlier articulation of this concept, Cohen (1972) made a distinction between institutionalised and non-institutionalised traveller that has been found to be useful in understanding individual behaviour at heritage sites. The application of Cohen's model enables one to conceptualise travel behaviour and experience at heritage sites in terms of their centrality and relevance to the individual's set of perceptions. Pearce (1982) also points out that not only do perceptions of place change after a visit but also the way tourists view their own country 
as a result of travel and the experience thereby gained.

This has led to a large number of typologies of heritage tourists proposed by various writers. In some cases, these are adaptations of what have been developed in other contexts; in other cases, they are developed directly for the purpose of classifying heritage tourists. Silberberg (1995), in a pioneering work, identified the cultural/heritage tourist as one who earns more money and spends more money while on vacation; spends more time in the area; is more highly educated than the general public; is more likely to be female than male; and tends to be in older age categories. Timothy (1997), provoking further discourse on the nature of heritage tourism experience based on the heritage space visited, identifies four levels of heritage attractions: world, national, local and personal. According to him, world heritage attractions invoke strong feelings and elicit many tourist visits. On the contrary, national, local and personal heritage attractions stimulate a much stronger feeling of personal connection that tends to facilitate different depths of experiences for tourists. Based on a study in Hong Kong, McKercher (2002) identified five types of cultural tourists: the purposeful, those for sightseeing, casual, incidental and the serendipitous. He then proposed a model to segment cultural tourism market according to the importance of cultural motives in the decision to visit a destination and depth of experience.

Drawing on earlier literature (e.g. Swarbrooke, 1993; Palmer, 1999), Poria et al. (2003) explored the existing typologies of heritage tourists that blended the demand and supply perspectives. The behavioural, motivational, perceptual and site attributes/awareness of heritage visitors were examined using their visitation pattern. The results of the study showed statistically significant association between visitation patterns and personal characteristics that were due to perceptions of the site in relation to respondents' own heritage. Consequently, they identified three types of heritage tourists: those visiting what they consider as heritage site although it is unconnected with their own; those visiting a place they deem to be part of their heritage, even though it may not be categorised as a heritage site; and

Copyright (c) 2010 John Wiley \& Sons, Ltd. those visiting a site specifically classified as a heritage place although unaware of this designation. It would be incorrect at this point, however, to leave the impression that this definition by Poria et al. (2003) has the blessing of many writers and authorities. Some authors consider the definition as narrow and question whether it may hold sway regarding the supply side of heritage tourism and that it needed to be tested in other contexts (Garrod and Fyall, 2001; Chabbra et al., 2003).

\section{THE STUDY AREA}

Danish-Osu (Wellington, 2007) became a favourite place when the capital of the then Gold Coast (now Ghana) was moved from Cape Coast to Accra in 1877. Like other seaside colonial towns, it is bounded to the south by the Atlantic Ocean, and defined by the western divide of old Dutch Accra and English Accra, the eastern expanse of the Klottey Lagoon and the Accra plains, laid out in gentle rising land to the foot of the Akwapim Ranges to the north. Danish-Osu's founding fathers sought to establish a community that mirrored their origins, and as a result by the nineteenth century it consisted of four quarters namely Kinkawe, Asante Blohum, Alata and Anohor (Parker, 1960; Figure 1).

Danish-Osu witnessed vigorous trade in gold and later slaves during the seventeenth century that attracted various European powers, brought commercial rivalry and made her an important town on the slave route in the country's south (Quaye, 1972; van Dantzig, 1982; Perbi, 2004). However, with the eventual monopoly of the eastern trade (area between Accra and the Volta River) exercised by the Denmark-Norway dominion, Danish-Osu became the Danish headquarters on the eastern stretch of the Guinea Coast lasting nearly two centuries.

Today, Danish-Osu serves as the seat of the government of Ghana and boasts of several public offices, residential areas of public officials, national monuments, tourist attractions, parks and gardens. Cantonments Road (now dubbed 'Oxford Street' after the popular Oxford Street in London), which was a colonial army station during World War II, has emerged as a leading leisure and recreational centre 


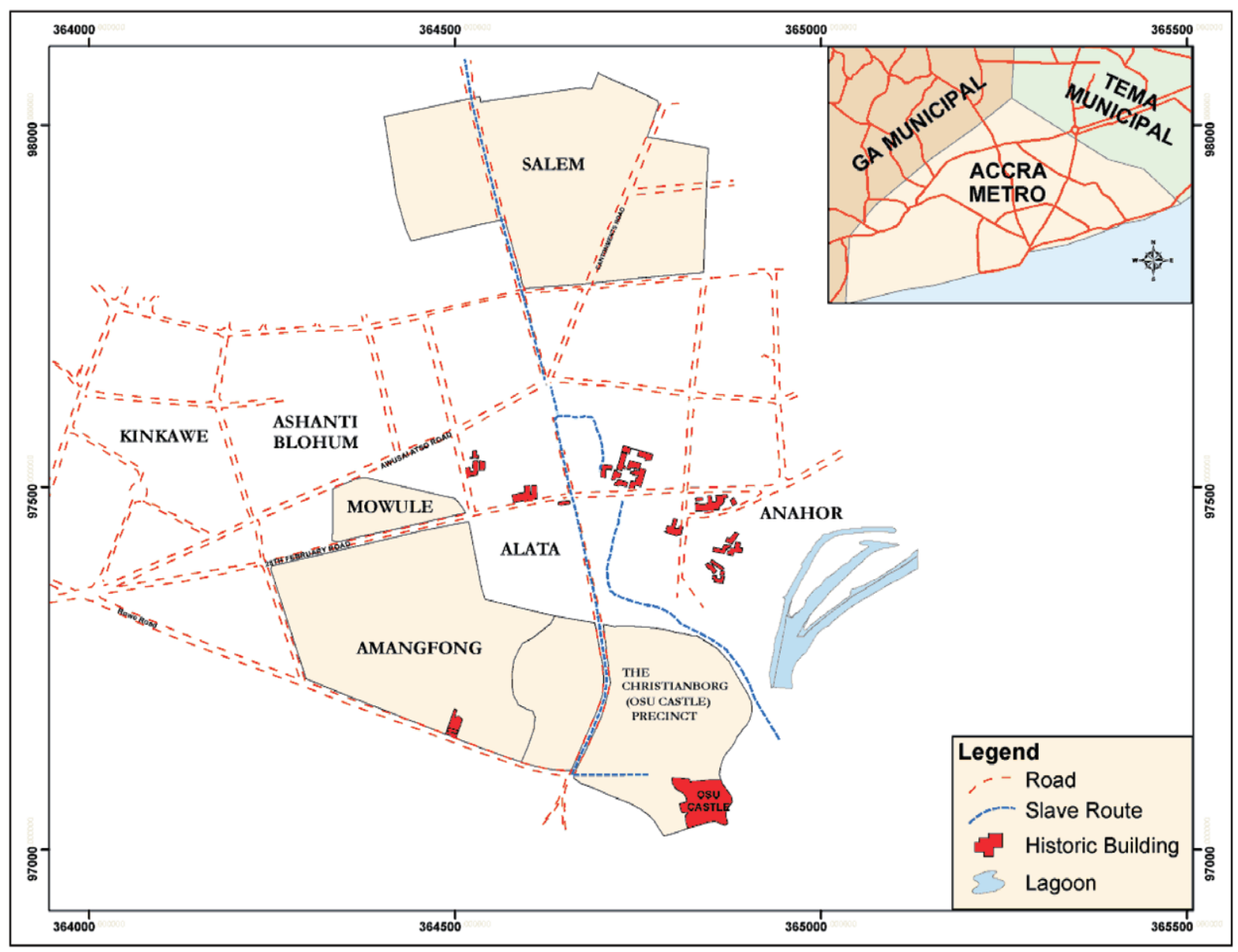

Figure 1. Map of Danish-Osu showing study areas (adapted from Wellington, 2007).

with a substantial number of banks, posh restaurants, hotels, boutiques and fast-food joints. The bustling cosmopolitan population and nightlife activities of the suburb compare with that of the central business district of Accra. This has made it a popular rendezvous for both international tourists and visitors to the capital. Such is the popularity and legacy of 'Oxford Street' that it can best be described as 'the most Oxford Street outside of England'.

Nevertheless, very little has been done to formally develop Danish-Osu as part of Ghana's vast array of TAST relics or a stop on the Ghana's Slave Route Project (SRP). This could be attributed to the current use of the Christiansborg Castle: as the seat of government since the colonial era, the magnificent edifice cannot be accessed by tourists. But interest in placing Danish-Osu on the coun- try's tourism circuit has been revitalised in recent times, with a decision in 2007 to include the community among the venues for PANAFEST/Emancipation Day/Joseph Project.

\section{METHODOLOGY}

The data analysed here are based on a larger empirical fieldwork conducted in Danish-Osu, details of which have already been published (Yankholmes et al., 2009). Given the population of interest in this study, the methodology followed the approach by Balcar and Pearce (1996). The assumption was that such an approach provided insights relevant for investigating the phenomenon under study.

The main research instrument was a semistructured questionnaire containing both open and close-ended questions. The first part dealt 
with general information on international tourists visiting Ghana using 10 items that asked tourists about their primary purpose of visits and trip characteristics. The second part covered a broad range of issues relating to tourists' knowledge of Danish-Osu as a tourist destination; respondents were asked to mention which attractions they had visited or intended to visit in Danish-Osu. The third part of the instrument explored tourists' attitudes and support for heritage tourism promotion in Danish-Osu; items elicited respondents' knowledge on the SRP and their support or otherwise for it as well as their perceptions of potential consequences of tourism development in the area. Taking a cue from Pearce et al. (1996), questions on perceptions about tourism required respondents to mention potential impacts of tourism rather than rate a list of tourism impacts on a Likert scale. The final part of the survey instrument dwelt on tourists' socio-demographic characteristics, e.g. sex, age, country of origin, nationality, highest educational attainment, marital status and employment status. Most of the items in the instrument were derived from the literature review, issues raised in personal conversations with some tourists to Ghana and the researchers' original ideas.

A pilot study of 50 tourists was carried out in Cape Coast (also a former slave site) for purposes of both pre-testing and refining the instrument to suit the Danish-Osu context. The main survey was conducted in 'Oxford Street' between October and December (the principal tourist season in Ghana for non-winter tourism) 2007. Based on Cohen's (1972) typology of tourists, institutionalised tourists were reached through travel and tour companies that brought groups of tourists to 'Oxford Street'. The authors, with the help of research assistants, administered the questionnaire to a random selection of them after permission was sought from tour guides accompanying them. Tourists were informed about the purpose of the survey after they had completed their visit. On the other hand, non-institutionalised tourists were interviewed on a random 'next-personto-pass' basis as they exited the tourist service and shopping belt (Powe and Willis, 1996). The interviews were conducted face to face and took about 25 minutes each. A limitation of the survey was that no data were gathered from other parts of the community, such as outlying hotels and attraction sites and, therefore, the sample may not be completely representative of all visitors to Danish-Osu.

These methods generated a total of 400 questionnaires, of which 218 (i.e. a 55\% response rate) were properly completed and provided usable data. Respondents consisted of 90 (41.3\%) institutionalised and 128 (58.7\%) noninstitutionalised tourists. The disparity in sampling was due mainly to the fixed nature of tourists' itinerary, especially among institutionalised tourists. Two reasons accounted for the relatively poor response rate: the transient nature of tourists and the absence of a sampling frame for a population of this nature. It could be deduced that many of the visitors to 'Oxford Street' come to eat, shop or transact business and, therefore, had little or no time to participate in the survey. Moreover, many tourists lamented over the 'harassment' they had to go through with street vendors. As one of them remarked, "being hassled by "Rastafarians" and souvenir peddlers is a huge problem for me; I hate being stared at like a mobile $\mathrm{ATM}^{\prime}$. Hence, although many of them were college students and volunteers, they were not keen in participating in the study. The data were analysed using the Statistical Package for Social Sciences software. Descriptive statistics were first used to profile the respondents. Second, chi-square and cross-tabulations were used to establish the extent of relationships between tourists' socio-demographic characteristics and their support for heritage tourism development.

\section{FINDINGS}

\section{Socio-demographic profile}

Nationality analysis produced the following profile of tourists to 'Oxford Street': 32 (14.7\%) British; 53 (24.3\%) Americans; 25 (11.5\%) Australians; 20 (9.2\%) Germans; 23 (10.6\%) Danes; 16 (7.3\%) French; 13 (6.0\%) Swedes; 17 (7.8\%) Canadians; and 19 (8.7\%) from West Africa. In terms of gender distribution, the sample was made up of more female $(64.2 \%)$ than male respondents; it was only among the Germans $(90.0 \%)$, Australians $(60.0 \%)$ and visitors from 
the West African sub-region (57.9\%) that males dominated the nationality sample. The unequal distribution of the sexes could be due to the reluctance of most male tourists to take part in the survey. Tourists were aged between 19 and 67 years with modal age group of $18-34$. Over $71 \%$ of the respondents were single, while $25.2 \%$ were married. The rest were divorcees / separated (1.4\%) and widowed (1.8\%). Gauged by their nationalities, the marital status of visitors showed immense variations: while the British, German, French, Canadian and those from West Africa registered large numbers $(100 \%)$ of singles, American $(71.7 \%)$ and Swedish $(100.0 \%)$ displayed high numbers of married visitors.

The educational attainment of the entire sample could be described as very high as $63.8 \%$ had received university education; $43.6 \%$ were employed compared with $29.8 \%$ and $8.7 \%$ who were students and unemployed respectively. Majority of British tourists $(81.3 \%)$ were students whereas most Americans $(69.8 \%)$ were retirees. Furthermore, the results show that besides Ghanaians living abroad and those from neighbouring West African countries (Nigeria, Togo, Cote d'Ivoire), the principal source regions were the USA, and Northern/Western Europe (UK, Germany, France, Sweden).

\section{Visitation pattern to Ghana}

Tourists' perception of heritage sites is linked to their visitation patterns as well as their own heritage (Poria et al., 2003). Trip characteristics explored in this analysis were length of stay, purpose of visit, motivation for visit, and pre- tour information on Ghana. Majority (88.5\%) of tourists to Ghana spent more than 10 days with an average of three. Nearly a third of respondents (30.3\%) acknowledged that their primary purpose of visiting Ghana was for pleasure/vacation while $23.4 \%$ were engaged on voluntary projects. The rest were research/ study $(20.2 \%)$, others (convention, visiting friends and relatives (24.8\%)) and work (1.4\%). This finding contradicts official sources that visiting friends and/or relations accounted for $25 \%$ of total arrivals to Ghana in 2006 (Ghana Tourist Board, 2008). Two out of every three respondents $(66.5 \%)$ stated that they were first time visitors, while $33.5 \%$ were repeat visitors, primarily as volunteers $(17.9 \%)$, holidaymakers $(10.1 \%)$ and researchers/students (5.5\%).

Respondents were asked to identify and rank their sources of information about Ghana; seven sources emerged: Internet links, travel companies, books, Bradt Travel Guide on Ghana, recommendations by friends and family, organizations sponsoring the trip and word-of-mouth (by people who had ever visited Ghana). Using the frequencies, the relative preference for the different sources of information was obtained (Table 1). The distribution shows that majority of tourists used Internet links (25.6\%), followed by Bradt Travel Guide (17.3\%) and friends and family (17.1\%) in that order. Upon arrival, majority (64.7\%) considered the sources to be 'reliable' compared with $27.1 \%$ and $8.3 \%$ who said 'somewhat' and 'not' reliable respectively. It was further observed that Bradt Travel Guide was the most favoured source for British tourists $(34.6 \%)$ and Australians $(29.1 \%)$, while the Internet was the most preferred source by

Table 1. Respondents' sources of information

\begin{tabular}{lccc}
\hline Source & Frequency & Percent (\%) & Rank \\
\hline Internet & 183 & 28.0 & 1 \\
Bradt Travel Guide & 116 & 17.3 & 2 \\
Friend and family & 113 & 17.1 & 3 \\
Books & 81 & 12.4 & 4 \\
Sponsoring organisations & 68 & 10.4 & 5 \\
Travel company & 49 & 7.5 & 6 \\
Word-of-mouth & 44 & 6.7 & 7 \\
Total & 654 & 100.0 & \\
\hline
\end{tabular}

The frequency count exceeds 218 because of multiple responses. 
Table 2. Tourists' perception of Ghana

\begin{tabular}{lcc}
\hline Attribute & Frequency & Percent $(\%)$ \\
\hline Not overrun by many tourists & 5 & 1.1 \\
Rich in cultural heritage & 137 & 31.4 \\
Great but more room for improvement in infrastructure & 128 & 29.4 \\
Lovely and hospitable people & 88 & 20.2 \\
Offers lots of opportunities for heritage tourism & 26 & 6.0 \\
Offers a large diversity of tourism products & 22 & 5.0 \\
Safe and a gateway to West Africa & 30 & 6.9 \\
Total & 436 & 100.0 \\
\hline
\end{tabular}

The frequency count exceeds 218 because of multiple responses.

Americans (12.9\%) and other tourists (23.1\%). The preference of Bradt Travel Guide could be attributed to the fact that it presented comprehensive travel information on Ghana (and Africa as a whole), particularly to first time visitors. This was also contrary to the findings of Amuquandoh and Ofori-Bah (2000) that internet links are preferred pre-tour information source for British tourists.

An aspect of the survey was on tourists' perception of Ghana as a tourist destination. Views on this differed markedly as $31.4 \%$ of respondents found Ghana's rich cultural heritage very appealing while $29.4 \%$ felt there was much room for improvement in infrastructure (Table 2). This may seem a surprising result given that only $20.2 \%$ of them reiterated the popular cliché that Ghanaians are hospitable. Akyeampong (2007) makes reference to official documents and interviews in which most visitors and diplomats underlined Ghana's hospitality credentials.

Among those tourists who perceive Ghana as rich in cultural heritage, $51.6 \%$ were repeat visitors, while $48.4 \%$ were first timers but spending more than 10 days in the country. Danish tourists $(26.9 \%)$ stressed that the country had a 'rich cultural heritage' compared with $4.6 \%$ of Americans, $2.3 \%$ of British and none by Canadian visitors who shared that view. The chi-square $\left(\chi^{2}\right)$ statistic was employed to determine whether significant relationship existed between tourists' country of origin and their perceptions of Ghana as a tourist destination. The existence of significant relationship was determined by comparing the $\rho$-values with the significant level set (0.05). The result showed that there is a significant relationship

Copyright (C) 2010 John Wiley \& Sons, Ltd. between country of origin and perceptions of Ghana as a tourist destination ( $p$ value $=0.01)$. This suggests that Danish tourists who thought Ghana had a rich cultural heritage were aware of her historical significance and felt the need to learn more even if they had visited previously.

\section{Knowledge and perceptions of Danish-Osu as a tourist destination}

Responses to questions relating to respondents' knowledge of Danish-Osu were generally not surprising. Some visited because it was a safe destination in Ghana $(4.6 \%)$, because Bradt Travel Guide recommends it (1.4\%) and in order to experience the local culture $(1.6 \%)$. Further analysis of responses to this question showed gender differences: male and female patrons accounted for $57.1 \%$ and $42.9 \%$ respectively to experience local culture. The reputation of Danish-Osu as a safe destination appealed to the sexes in the ratio of four to one in favour of males.

In a subsequent question, $75.2 \%$ of respondents stated that they were aware that DanishOsu was a major slave market during the TAST, while $17.0 \%$ and $7.8 \%$ said 'no' and 'didn't know' respectively. The huge number of respondents who responded in the affirmative said they got to know Danish-Osu was a slave market through Internet search $(20.6 \%)$, Bradt Travel Guide (16.3\%), from lectures back home $(13.3 \%)$, word-of-mouth $(10.1 \%)$, from earlier visits $(8.3 \%)$, by a tour guide $(5.0 \%)$ and as a result of their own research $(1.8 \%)$.

Nearly all respondents $(96.7 \%)$ could mention some TAST relics or monuments in 
Table 3. Reasons for supporting decision to convert Christiansborg Castle into a tourist site

\begin{tabular}{lcc}
\hline Reason & Frequency & Percent $(\%)$ \\
\hline It is a source of rich cultural heritage. & 17 & 7.8 \\
It helps to document and retell the stories of Transatlantic Slave Trade. & 24 & 11.0 \\
It is a part of 'my' - Danish - heritage & 67 & 30.7 \\
It broadens the attraction base of Danish-Osu & 17 & 7.8 \\
Do not know & 93 & 42.7 \\
Total & 218 & 100.0 \\
\hline
\end{tabular}

Danish-Osu besides the Christiansborg Castle. Prominent among those mentioned were Richter's Fort (28.4\%), Salem Road (24.3\%), Frederich Minde (20.2\%), Lutterodt Family House $(14.7 \%)$ and Nii Okantey Shiikatse Trading House $(12.4 \%)$. (As of today, with the exception of the Christiansborg Castle, all these monuments draw a trickle of mostly Danish tourists and expatriates.) On government's intention to make the Christiansborg Castle a tourist attraction, $57.3 \%$ of respondents supported the idea; $17.9 \%$ did not, while some $24.8 \%$ were indifferent. Reasons for supporting the proposed project were mostly because, to the Danes in particular, the castle was part of their heritage (30.7\%; Table 3).

Table 3 shows that for respondents, the decision to make the Christiansborg Castle a tourist attraction would serve good purpose and would help to document and conserve the history of the TAST (11.0\%). For Danish tourists $(31.3 \%)$, it was part of 'their heritage' compared with German (26.9\%), Swedish (19.4\%), Australian (17.9\%), American (1.5\%) and British $(1.5 \%)$ visitors who also related to the monument in one way or the other. A chisquare $\left(\chi^{2}\right)$ statistic showed a significant relationship between tourists' country of origin and their reasons for supporting the decision to make Christiansborg Castle a tourist attraction ( $p$ value $=0.000$ ). This is analogous to the earlier observation where Danish tourists claimed they visited Ghana because of her rich history. It can thus be envisaged that the promotion of heritage tourism with the Christiansborg Castle as one of the core attractions will enhance the overall appeal of Danish-Osu as a tourist destination. (It must be noted that at the moment, tourists' mostly Ghanaian nationals and researchers must give one month

Copyright (c) 2010 John Wiley \& Sons, Ltd. notice to the authorities in order to be permitted entry to the Castle.)

A greater percentage of respondents (78.4\%) agreed that 'the memory of the TAST should be revisited'; $19.7 \%$ disagreed with the statement while $1.8 \%$ of them did not have any opinion. An overwhelming majority (90.8\%) of respondents agreed with the statement that 'TAST relics and monuments should be developed for tourism purposes' in Danish-Osu, while $7.8 \%$ disagreed and another $1.4 \%$ did not proffer any opinion. In general terms, one interesting result was that, in relation to each of the two statements, less than $2 \%$ of respondents indicated that they did not have any strong feelings about the issues.

\section{Attitude and support for heritage tourism in Danish-Osu}

The first question in the final part of the questionnaire aimed at establishing levels of respondents' awareness of the SRP. Over half $(59.2 \%)$ of the respondents stated that they were aware of the SRP, while the rest did not. In a follow-up question, respondents who answered 'yes' were asked to indicate what they knew about the SRP. A fifth (20.2\%) of them indicated that the SRP was linked to the preservation of TAST-related sites; another $17.0 \%$ stated that it was aimed at breaking the silence on the TAST and $15.6 \%$ were even more specific by naming some related events being promoted by UNESCO. A further $6.4 \%$ thought that the SRP was a way of fostering coexistence among the peoples of the world.

To the second question, just over half of the sample (54.1\%) expressed their support for the SRP compared with $21.1 \%$ who were against it and $24.8 \%$ who were indifferent. In terms of 
nationalities, however, the cross-tabulation showed that $65.2 \%$ of Danish tourists disagreed to this question even though almost $30 \%$ of them had indicated that the Christiansborg Castle Ghana was part of their heritage. Against the emotional undercurrents about the TAST, this position was not surprising. Discussions done after administering the questionnaires with a number of Danish nationals, including one diplomat at the Danish High Commission in Ghana, showed that the existence of Danish mulattos and slave descendants in Danish-Osu brings painful memories so while some Danes felt proud about the castle built by their forebears, there are others who would rather not want to be reminded about the slavery with which it came to be associated.

Respondents were asked how Danish-Osu could be promoted as a former slave site. A greater proportion $(36.2 \%)$ thought that creating an internet website would be helpful while $20.6 \%$ recommended a tourist information office on 'Oxford Street'. Others mentioned exhibitions (15.1\%), developing historical sites $(12.8 \%)$, functional signage $(11.9 \%)$ and through brochures, book and magazines $(3.2 \%)$. There were, however, some significant variations by sex, age and highest educational attainment with respect to the media for promoting Danish-Osu. Whereas 37.2\% of males preferred the provision of tourist information office, $46.4 \%$ females favoured a website. On age cohorts, those in the 18-34 brackets wished for tourist information office as compared with those between 35 and 50 years who preferred exhibitions. Respondents of over 50 years recommended the development of historical sites to promote Danish-Osu as a former slave site. Over $69 \%$ of tourists with secondary education suggested a website (on the Internet); 30.9\% of university graduates were for tourist information office while $50 \%$ of those with postgraduate qualifications preferred promotion of Danish-Osu through exhibitions.

The final set of questions elicited tourists perceptions about the potential consequences of tourism for Danish-Osu. This open-ended question produced a very large range of responses that were categorised using a detailed process by Miles and Huberman (1994) as a guide. Responses were first grouped into combined categories and then re-analysed to ensure that responses fitted categories, or created new categories (Table 4).

Differences were observed in some dependent variables; for instance, on educational

Table 4. Nature of potential impacts perceived by tourists

\begin{tabular}{lrr}
\hline Nature of response & Frequency & Percent (\%) \\
\hline Positive & & 31.9 \\
Improved incomes and standard of living & 139 & 32.1 \\
Increased investment and development & 140 & 8.5 \\
Job creation for local residents & 37 & 9.9 \\
Improved provision of social amenities & 44 & 3.9 \\
Philanthropy/chances for scholarship for locals & 17 & 13.8 \\
Increased knowledge about and visits to Transatlantic Slave Trade sites & 60 & 100.0 \\
Total & 436 & 6.2 \\
Negative & & 14.2 \\
Increased traffic congestion & 27 & 16.5 \\
Increased rent and cost of living & 62 & 21.3 \\
Crime against tourists & 72 & 12.6 \\
Noise and overcrowding & 93 & 13.5 \\
Hassling and begging & 55 & 8.5 \\
Cultural change/acculturation & 60 & 7.2 \\
Littering & 37 & 100 \\
Tncreased foreign domination of tourism businesses & 30 & 436 \\
\hline
\end{tabular}

The frequency count exceeds 218 because of multiple responses. 
attainment, $75 \%$ of university graduates intimated that tourism would lead to 'increased knowledge about and visitations to TAST sites' compared with $23.3 \%$ and $1.7 \%$ respectively of those with secondary and post-graduate qualifications who shared that view. A slightly greater proportion of those with university education also indicated that tourism would lead to 'improved incomes and standard of living' and 'improved social amenities'. Similarly, respondents' views about potential negative consequences reflected their educational levels; as many as $67.7 \%$ of those with secondary education felt that tourism development would lead to 'increased cost of living' compared with only $30.6 \%$ and $1.6 \%$ respectively of those with university degrees and postgraduate qualifications who held that view. Furthermore, $56.9 \%$ of those with secondary education referred to 'crime against tourists' as a potential negative outcome of tourism compared with $1.4 \%$ of post-graduates. 'Increased foreign domination of local tourism businesses' was also identified by $86.7 \%$ of those with university education. Over half $(51.7 \%)$ of the university graduates were also the only category to point to 'cultural change/acculturation'. On their part, those with secondary education identified 'increased traffic congestion' $(7.4 \%)$, and 'increased noise and overcrowding' (15.1\%) as potential negative fallout for the study area.

\section{DISCUSSION AND CONCLUSIONS}

The tourist's sense of heritage gaze shares much with perceptions, but differs in significant ways. Following the suggestion for 'psychographic' approach in segmenting heritage tourism (Poria et al., 2006a, 2006b) tourists to 'Oxford Street' share this quality. The survey results indicate that majority of foreign visitors are pleasure/vacation seekers and first-time visitors $(66.5 \%)$ who come to experience the country's tourism products. It also came to light that majority of respondents were volunteers, medical practitioners and students. In Ghana, the unique attribute of volunteer tourists is the fact that they mostly stay with host families during the entire period. They are normally provided with breakfast and supper, and often take lunch outside home. Normally, the last two weeks of their stay is dedicated to travelling around the country. More importantly, they draw up their own itinerary and arrange for their own transportation and accommodation, which normally are the cheapest available. Consequently, as far as the concept of non-institutionalised tourism (Cohen, 1972) goes, such people fit the description well.

The findings also indicate that Internet links are the most important information source for international visitors to Ghana. Tourist guide books (particularly Bradt Travel Guide on Ghana) and friends and family are the second most important sources. This confirms the finding of Buhalis (1998) that increasingly the Internet has become a tool for planning schedules and searching for and buying travel products. In terms of their perceptions of Ghana as a tourist destination, $31.4 \%$ perceive Ghana as rich in cultural heritage while others claimed there was more room for improvement in infrastructural facilities.

Although the sample size does not provide enough basis to extrapolate the major findings, the observation that Danish tourists perceive Danish-Osu as part of their heritage confirms the findings of Bruner (1996) that different visitors are interested in diverse aspects of interpretation at heritage sites and provides the impetus for legacy tourism (McCain and Ray, 2003). The significance of Danish tourists visiting Danish-Osu highlights the triangular relationship between the tourists, the site visited and the actual experience gained or experienced (Timothy, 1997; McKercher and du Cros, 2002; Poria et al., 2006b). Thus, just as Dutch tourists prefer to learn about Dutch rule in Elmina-about $140 \mathrm{~km}$ west of Accra-it stands to reason that the Danes are also interested in the Danish involvement in precolonial trade along the Guinea Coast. For this reason, tourists to Danish-Osu are what Cohen (1979) has called 'experiential tourists'; visitors whose experiences are characterised by the experiential mode. They see their visit as a quest for meanings within the confines of their own heritage, a search for authentic experiences. Even though the experience of their visits has recreational and diversionary elements, they clearly identify with the site.

Thus, it is important that any target marketing programme should take cognizance of 
socio-psychological characteristics of tourists and the attributes of the heritage site concerned. As succinctly put by Ashworth (1988, p. 172) 'it is not enough to make broad unsupported assumptions about nostalgia, escapism or romanticism, if the heterogeneous markets for and extremely heterogeneous product is to be understood'. The expectations of tourists are conditioned by their experience and desires of the site that for all intents and purposes have the potential of causing dissatisfaction where tourists' experience is not matched by pre-tour expectations. Moreover, the choice of heritage attraction and the extent of experience depend largely on the information available to the potential tourists. Some of the information may originate from the National Tourism Organization and other agencies specialised in marketing a destination. In Ghana, this is the responsibility of the Ghana Tourist Board. It is based on this information that the tourist makes not only the decision to travel to a particular heritage site but more importantly, the decision on the length of stay.

Respondents were able to mention some TAST relics such as the Richter's fort, Salem Road and Frederichs Minde as the leading attractions in Danish-Osu. Significantly, 57.3\% of the respondents support the government's decision to make the Christianborg Castle a tourist attraction in order to revisit the memory of the slave trade. For most $(90.8 \%)$ of the respondents, this could help to preserve many of the numerous slave trade relics of DanishOsu as it is likely to exert a stronger pull on tourists.

Similarly, 59.2\% are aware of the SRP, which they think is linked to the preservation of sites associated with TAST (20.2\%). Consequently, $54.1 \%$ support the SRP but Danish tourists were not so enthused about it. This finding suggests that in the light of the literature on the use of heritage as a means to construct identity (Lowenthal, 1985) and the literature centred on dissonant heritage (Tunbridge and Ashworth, 1996), certain groups of tourists may prefer to recognise some heritage sites as 'world' but not 'personal' (Timothy, 1997). As demonstrated in the study, for Danish visitors, recounting memories of TAST could hurt the community bearing in mind the existence of slave descendants. This also supports the find- ings by Poria et al. 2006b that some segments of heritage tourists get emotionally involved and assign personal meaning to artefacts presented at heritage sites. Yet, TAST relics in Danish-Osu are visible consequences of the need for the community's continuity whether they were founded under the umbrella of 'embarrassment of the past' or heritage tourism development (Yankholmes et al., 2009).

Although the present study is a snapshot of a particular time and location, assessing tourist perceptions of possible impacts when tourism has not taken root was important as it had the potential of assisting in the planning process. In this study, respondents' perceptions about the potential fallout of tourism of development, whether positive or negative, were influenced by their socio-demographic background. In particular, differences in respondents' perceptions were related to their educational attainment. Thus, differences based on educational attainment in relation to perceptions of tourism development in heritage sites could be the basis for further research.

The current study also holds ethical implications for interpreting different heritage types for tourists at 'contested' sites. Austin's (2000) caution that utilising the historic events of the slave trade for tourism could potentially incite racism among black people and toward whites is a moot point. In the case of Danish-Osu, not only does it pose a challenge in utilising the history of the slave trade for tourism purposes but, more importantly, it raises emotions about people's ancestry. Interpretation not only encourages research into, and enhances our current understanding of the historic TAST and its manifestations in former slave sites, but it should also enable us to decide on cultural heritage management best practices. This can be done through information management about TAST resources and understanding the historical antecedents of Danish-Osu community. Miller (1989) stresses the need for a balance between the needs of the resource and of the visitor, and in this instance a balancing act in interpreting TAST resources for tourism development becomes an imperative. However, it is essential that the potential tourist receive such information before the critical decisions about travel are made. With regard to the Danish-Osu community, the question of what 
information to give to tourists and how the information should be managed and disseminated is of paramount importance.

\section{REFERENCES}

Akyeampong OA. 2007. Tourism in Ghana: The Accommodation Sub-sector. Janel Publications Limited: Accra.

Amuquandoh FE, Ofori-bah E. 2000. Information sourcing and utilization by international visitors to Ghana: a study in information search in tourism. Bulletin of the Ghana Geographical Association 22(1): 55-66.

Ashworth G. 1988. Marketing the historic city for tourism. In Marketing in the Tourism Industry: The Promotion of Destination Regions, Ashworth G, Goodall B. (eds). Billing \& Sons Limited: Worcester; 162-173).

Austin NK. 2000. Tourism and the transatlantic slave trade: some issues and reflections. In Political Economy of Tourism in Africa, Dieke P (ed). Congnizant Publications: New York; 208-216).

Austin NK. 2002. Managing heritage attractions: marketing challenges at sensitive historical sites. International Journal of Tourism Research 4(6): 447-457.

Balcar JO, Douglas GP. 1996. Heritage tourism on the West Coast of New Zealand. Tourism Management 17(3): 203-212.

Best M. 2007. Norfolk Island: thanatourism, history and visitor emotions. Shima: The International Journal of Research into Island Cultures 1(2): 30-48.

Blackburn K. 2000. Commemorating and commodifying the prisoner of war experience in south-east Asia: the creation of Changi Prison Museum. Journal of the Australian War Memorial 33: 1-18.

Boakye KAA, Dei LA. 2007. Developing the slave route for tourism: community dynamics, policy implications, and strategies for the root tourism product. In Transatlantic Slave Trade: Landmarks, Legacies, Expectations, Anquandah JK, OpokuAgyemang NJ, Doortmont MR (eds). Proceedings of the International Conference on Historic Slave Route. Sub-Saharan Publications: Accra; 347-357.

Bremer TS. 2004. Blessed by Tourists: The Borderlands of Religion \& Tourism in San Antonio. University of North Carolina Press: Chapel Hill.

Bruner EM. 1996. Tourism in Ghana: the representation of slavery and the return of the Black Diaspora. American Anthropologist 98(2): 290-304.

Buhalis D. 1998. Strategic use of information technologies in the tourism industry. Tourism Management 19(5): 409-421
Chhabra D, Healy R, Sills E. 2003. Staged authenticity and heritage tourism. Annals of Tourism Research 30(3): 702-719.

Cohen E. 1972. Towards a sociology of international tourism. Social Research 39(1): 164-189.

Cohen E. 1974. Who is a tourist? A conceptual classification. Sociological Review 22(4): 527-555.

Cohen E. 1979. A phenomenology of tourist experience. Sociology 13(2): 179-201.

Foley M, Lennon JJ. 1996. JKF and dark tourism: a fascination with assassination. International Journal of Heritage Studies 2(2): 198-211.

Garrod B, Fyall A. 1998. Beyond the rhetoric of sustainable tourism. Tourism Management 19(3): 199-212.

Garrod B, Fyall A. 2001. Heritage tourism: a question of definition. Annals of Tourism Research 28(4): 1049-1053.

Ghana Tourist Board. 2008. Tourism Statistical Factsheet on Ghana. Available at http://www. touringghana.com/documents/facts_\&figures/ (accessed 15 August 2009).

Herbert D. 2001. Literary places, tourism and the heritage experience. Annals of Tourism Research 28(2): 312-333.

Lennon JJ, Foley M. 1999. Interpretation of the unimaginable: the U.S. Holocaust Museum, Washington, D.C. Journal of Travel Research 38(1): 46-50.

Lowenthal D. 1985. The Past Is a Foreign Country. Cambridge University Press: Cambridge.

McCain G, Ray NM. 2003. Legacy tourism: the search for personal meaning in heritage travel. Tourism Management 24(6): 713-717.

McKercher B, 2002. Towards a classification of cultural tourists. International Journal of Tourism Research 4(1): 29-38

McKercher B, du Cros H. 2002. Cultural Tourism: Partnership between Tourism and Cultural Heritage Management. Haworth Press: Binghamton, New York.

Meyersohn R. 1981. Tourism as a Socio-economic Phenomenon: Research Perspectives. Research paper number 3. Otium Publications: Waterloo.

Miles MB, Huberman AM. 1994. Qualitative Data Analysis. Sage: London.

Miller S. 1989. Heritage management for heritage tourism. Tourism Management 10(1): 9-14.

Palmer C. 1999. Tourism and the symbols of identity. Tourism Management 20(3): 313-321.

Parker J. 1960. Making the Town: Ga State and Society in the Early Colonial Accra. Heinemann: Portsmouth, HN.

Pearce PL. 1982. The Social Psychology of Tourist Behaviour. Pergamon Press: Oxford.

Pearce PL, Moscardo G, Ross GF. 1996. Tourism Community Relationships. Pergamon: Oxford. 
Peleggi M. 1996. National heritage and global tourism in Thailand. Annals of Tourism Research 23(2): 432-448.

Perbi AA. 2004. A History of Indigenous Slavery in Ghana from the 15th to the 19th Century. SubSaharan Publications: Accra.

Poria Y, Butler R, Airey D. 2001. Clarifying heritage tourism. Annals of Tourism Research 28(4): 1047-1049.

Poria Y, Butler R, Airey D. 2003. The core of heritage tourism. Annals of Tourism Research 30(1): 238-254.

Poria Y, Reichel A, Biran A. 2006a. Heritage site management: motivations and expectations. Annals of Tourism Research 33(1): 162-178.

Poria Y, Butler R, Airey D. 2006b. Tourist perceptions of heritage exhibits: a comparative study from Israel. Journal of Heritage Tourism 1(1): 5172.

Powe NA, Willis KG. 1996. Benefits received by visitors to heritage sites: a case study of Warkworth Castle. Leisure Studies 15(4): 259 275.

Quaye I. 1972. The Ga and her neighbours 1600-1742. Doctoral Dissertation, History Department, University of Ghana.

Rojek C. 1993. Ways of Escape: Modern Transformations of Leisure and Travel. Macmillan: London.

Seaton A. 1996. From thanatopsis to thanatourism: guided by the dark. International Journal of Heritage Studies 2(4): 234-244.

Seaton A. 1999. War and Thanatourism: Waterloo 1815-1914. Annals of Tourism Research 26(1): 130-158.

Silberberg T. 1995. Cultural tourism and business opportunities for museums and heritage sites. Tourism Management 16(5): 361-365.
Strange C., Kemp M. 2003. Shades of dark tourism: Alcatraz and Robben Island. Annals of Tourism Research 30(2): 386-405.

Swarbrooke J. 1993. The future of heritage attractions. Insights 4: D15-D20.

Teye VB, Timothy DJ. 2004. The varied colours of slave heritage in West Africa: White American stakeholders. Space and Culture 7(2): 145-155.

Timothy DJ. 1997. Tourism and the personal heritage experience. Annals of Tourism Research 34: 751-754.

Timothy DJ, Boyd SW. 2006. Heritage Tourism in the 21st Century: valued traditions and new perspectives. Journal of Heritage Tourism 1(1): 1-16.

Tunbridge J, Ashworth G. 1996. Dissonant Heritage: The Management of the Past as a Resource in Conflict. Wiley: Chichester.

van Dantzig A. 1982. Forts and Castles of Ghana. Sedco: Accra.

Walter T. 2001. From cathedral to supermarket: mourning, silence and solidarity. The Sociological Review 49(4): 494-511.

Wellington HNR. 2007. Exhibition on Danish-Osu. Goethe Institut: Accra.

Wight AC, Lennon JJ. 2007. Selective interpretation and eclectic human heritage in Lithuania. Tourism Management 28(2): 519-529.

Yale P. 1991. From Tourist Attraction to Heritage Tourism. 2nd edn. Elm Publications: Huntingdon.

Yankholmes AKB, Akyeampong OA, Dei LA. 2009. Residents' perceptions of Transatlantic Slave Trade attractions for heritage tourism in DanishOsu, Ghana. Journal of Heritage Tourism 4(4): 315-329.

Young J. 1993. The Texture of Memory: Holocaust Memorials and Meaning. Yale University Press: New Haven. 